\title{
The Law Enforcement against Justice of Criminal Thicking
}

\section{Nurokhid ${ }^{*}$ and Achmad Sulchan ${ }^{* *}$}

*) Student of Master of Law Program, Faculty of Law Universitas Islam Sultan Agung email nurokhid.advc@gmail.com

${ }^{* *}$ F Faculty of Law Universitas Islam Sultan Agung

\begin{abstract}
.
The purpose of this research is to find out and analyze law enforcement against the perpetrators of criminal theft in Kendal Police, to analyze the factors that influence law enforcement against perpetrators of criminal acts of theft at Polresrang, obstacles that arise in the process of enforcing criminal acts of theft at the Police. Kendal with justice and efforts to overcome it the approach method used is sociological juridical method, the specification in this research is descriptive analytical. The results of the research are that in carrying out law enforcement refers to the Criminal Procedure Code and the Criminal Code and the National Police Perkap No. 6 of 2019 concerning criminal investigation, and Perma No. 2 of 2012 regarding the adjustment of the limitations of minor crimes and the amount of fines in the Criminal Code, the application of criminal acts against theft. Factors affecting law enforcement against the perpetrators of criminal theft at the Kendal Police are just. The obstacles faced are slow reports from the public to the authorities, damage to the crime scene/crime scene, lack of awareness of the public to be witnesses, lack of personnel from members of the police in conducting investigations, lack of necessary facilities and infrastructure such as less sophisticated equipment.
\end{abstract}

Keywords: Law Enforcement; Crime; Theft; Justice.

\section{Introduction}

Along with the development of criminal case problems in Indonesia, a form of resolution that prioritizes substantial justice is urgently needed. This substantial justice will guarantee the rights of the parties, as well as restore social harmony in society. Recently, the settlement of criminal cases has caused dissatisfaction in the community. This is because criminal law enforcement tends not to provide a sense of justice for the poor. ${ }^{1}$

A good legal rule will certainly not be useful if it is not enforced. For that, it requires quality resources and facilities or infrastructure that support it. Apart from that, broad community support is a prerequisite for the realization of just law enforcement. Enforcement of criminal law with negative sanctions should be seen as a last resort or subsidiary, namely by prioritizing types of sanctions in other areas of law, and if criminal law is to be involved then lighter sanctions should be used among the many alternative sanctions that are threatened. ${ }^{2}$

In order to improve law enforcement, it is necessary to strengthen the

\footnotetext{
1 Muhammad Taufiq, "Penyelesaian Perkara Pidana Yang Berkeadilan Substansial" in Yustisia Vol.2 No.1 January - April 2013, https://jurnal.uns.ac.id/yustisia/article/viewFile/11058/9896

2 Achmad Sulchan, Akhmad Khisni, and Aryani Witasari. (2020). Pola Pembinaan Narapidana Yang Berkeadilan. Semarang: Unissula Press. p.1
} 
position and role of law enforcement agencies in accordance with their respective authorities, as well as to improve their capabilities and authority, and to develop attitudes and behavior and exemplary law enforcers in accordance with their functions, namely as protectors of an honest, clean society, firmly, professionally fair. So that members of the community can realize, live and implement their rights and obligations as citizens in order to achieve law enforcement of justice and protection of human dignity and legal certainty for the formation of behavior of Indonesian people who are obedient and obedient to existing laws.

The purpose of criminal procedural law is to seek and obtain or at least approach material truth, namely the complete truth of a criminal case by applying the provisions of criminal procedural law honestly and accurately, with the aim of finding out who the perpetrator can be accused of committing a crime violation of the law, and then request an examination and decision from the teacher's court to determine whether it is proven that a criminal act has been committed and whether the person accused can be blamed

Criminal procedural law is closely related to criminal law. In fact, criminal procedural law is included in the definition of criminal law. Criminal law is often called sanetie law, which is a threat to be carried out by means of the public (State) agency of the court, if a rule of law is violated. In other words, criminal law is all regulations covering all regulations which, if violated, are punishable

Legislative provisions regulating procedures so that perpetrators of violations and crimes can be brought before a court session are called formal criminal law. In other words, formal criminal law is a collection of legal regulations that contain provisions governing matters as follows

- What actions should be taken if there is a suspicion that a criminal act has been committed by someone.

- If it is true that a criminal act has been committed by someone. It is necessary to know who the perpetrators are and how to investigate the perpetrators.

- If the perpetrator is known, the investigator needs to arrest, detain then proceed with a preliminary examination or carry out an investigation.

- In order to prove whether the suspect actually committed a criminal act, it is necessary to collect evidence, search properties and places and confiscate evidence that is suspected of having something to do with the act.

- After a preliminary examination or investigation by the police has been completed, the case file is submitted to the district attorney, then the examination in court against the defendant by a judge until a criminal is imposed. $^{3}$

The crime that is increasingly rampant today is theft. This is because it is increasingly difficult to find work opportunities so that there is a lot of unemployment and also because the economic conditions are deteriorating (difficult). The development of crime, especially the crime of theft, is increasing, which is a negative impact of the progress that has been made by our country. For example, the criminal act of theft which is mostly committed by someone is due to the deteriorating economic structure caused by frequent increases in the price of

\footnotetext{
${ }^{3}$ Moch Faisal Salam. Hukum Acara Pidana dalam Teori dan Praktek. Jakarta: Mandar Maju. p 1-3
} 
goods and quite high inflation while the distribution of income for the community is not evenly distributed, and also the high unemployment rate is caused by the difficulty of getting a job.

Other things that support a person committing the crime of theft are also caused by several factors including environmental influence, the opportunity to commit the crime, lack of awareness of the law of the perpetrator and can be caused by other social factors. According to the Criminal Code, theft is taking something that belongs to another person by violating the rights of others, we can see in Article 362 of the Criminal Code which states: "Anyone who takes an object partly or wholly belongs to another person, with the intention of controlling the object. Unlawfully guilty of theft, shall be punished with a maximum sentence of five years or a maximum fine of nine hundred rupiahs". ${ }^{4}$

Considering the Mrs. Minah's old age, of course it is very appropriate that the process of resolving the case with restorative justice, namely the peace between the two parties between the reporter and the reported at the investigation level and the case will not continue.

Based on the description above, this study aims to determine and analyze law enforcement against the perpetrators of criminal theft at the Kendal Police who are just, to analyze the factors that influence law enforcement against the perpetrators of criminal theft at the Kendal Police who are just, the obstacles faced and the solutions in law enforcement against perpetrators of criminal acts of theft at the Police

\section{Result and Discussion}

\subsection{Law Enforcement against Perpetrators of Crime of Theft at the Justice Kendal Police}

To find out the fair implementation of law enforcement against cases of theft at the Kendal Police, the following describes cases of theft in the Kendal Police jurisdiction.

As for The case that occurred was the alleged criminal act of theft that occurred on Monday, May 162020 at around 02.30 WIB at Mr. Tusrin, Purwosari village RT 21 RW 04 Dist. Patebon Reg. Kendal based on Tusrin's complaint letter dated May 18, 2020 as referred to in article: 362 of the Criminal Code carried out by Suyatmin bin Tomo, place of birth of Kendal on November 26, 1968, freelance daily labor, religion, Islam, male-male gender, Indonesian/Javanese nationality, education last elementary school (did not pass), residential address Jambearum Rt 02 RW 04 Dist. Patebon Reg. Kendal. Violates Article 362 of the Criminal Code.

The facts that occurred: During the summons: (1) Without a summons, the witnesses Bro. Samsuri, place of birth date Kendal, 7 October 1967 male gender, work self-employed, address Purwosari RT 021 RW 04 Dist. Patebon Reg. Kendal, on Wednesday, 18 May 2020. Carrying Orders: In this case the carry orders were not carried out. Arrest: No arrests were made, because they were caught in the hands of the local police, and were summoned by the police apparatus and their families for mediation. Detention: No detention was carried out because there were efforts at

${ }^{4}$ https://sarjanahukumasli.blogspot.com/2018/05/makalah-tindak-pidana-pencurian.html 
peace because the amount of losses was small Confiscation: 4 coconut kernels were confiscated and returned to their owners at the Police. Search: No search was carried out because the evidence in the form of 4 coconut kernels was taken to the Police. Witness statement: Samsuri, place of birth date Kendal, 7 October 1967 male gender, self-employed, address Purwosari RT 021 RW 04 Dist. Patebon Reg. Kendal.

The suspect's testimony: Suyatmin bin Tomo, place of birth in Kendal 26 November 1968, freelance daily labor, Islam, male gender, Indonesian/Javanese citizenship, last elementary education (did not pass), residence address Jambearum Rt 02 RW 04 Dist. Patebon Reg. Kendal.

Explain: That the suspect testified that he was physically and mentally healthy and was willing to be examined and was able to provide truthful information. The suspect understood that he was examined as a suspect in connection with the alleged criminal act of theft of 4 (four) coconut seeds which occurred on Saturday, May 16, 2020 at around 02.30 WIB at Mr. Tusrin joined Vill. Purwosari Rt 21 RW 04 Dist. Patebon Reg. Kendal, based on Mr. Tusrin dated 18 May 2020. Whereas before this the suspect has never been convicted or involved in any other crime. In this examination I will face it myself and do not use the help of a lawyer or legal advisor and the examination can be continued.

That the suspect was summoned by officers from the Kendal Police area on Saturday 18 May 2020 at around 10.30 WIB at Purwosari RT 021 RW 04 Dist. Patebon Reg. Kendal, that the suspicion that the suspect had committed the alleged theft was correct. That the suspect committed this act on Saturday, May 162020 at around 02.30 WIB at Mr. Tusrin, Purwosari village RT 21 RW 04 Dist. Patebon Reg. Kendal.

That the victims in the crime of theft are:

Mr. Tusrin, place of birth date Kendal, June 2, 1986, Islam religion, Entrepreneur Job having his address at Purwosari village RT 21 RW 04 Dist. Patebon Reg. Kendal.

Confrontation: In this case the investigator confronts the witnesses or the suspect. Evidence: 4 (four) coconut seeds

Based on the case above, the case analysis is as follows:

That the suspect, Suyatmin bin Tomo, committed a criminal act of theft which occurred on Saturday, May 16, 2020 at around 02.30 WIB at my house, I did not know he joined Purwosari Village rt 21 Rw 04 Dist. Patebon Reg. Kendal. The suspect is Br. Suyatmin bin Tomo.

Based on the case analysis above, there are indications that the suspect is Bro. Suyatmin bin Tomo has alleged the crime of theft as referred to in Article 362 of the Criminal Code.

- Elements of Whom

Is a person with sound mind so that his actions can be accounted for, in this case the suspect is Bro. Suyatmin bin Tomo (Born in Kendal on November 26, 1968, male gender, Indonesian nationality, Islam, freelance daily labor, address/residence: Village Jambearum Rt 02 Rw 04 Dist. Patebon Reg. Kendal Regency

- Take goods

Based on witness testimony and confirmed by the suspect that mr. Suyatmin bin 
Tomo took 4 coconut seeds in a basket outside the house of an unknown person.

- Where the goods are partly or totally/completely owned by other people.

Based on the testimony, witnesses and corroborated by the suspect's statement that the item to be taken is not the suspect's property but the victim's Tusrin

- With the intention of wanting to own these items against the right.

Based on the suspect's statement that the item did not belong to him and the item belonged to the victim Tusrin, and in taking the item the suspect did not give the permission of the owner.

- Done in the early morning

Based on witness testimony and the suspect's own testimony, the suspect committed the act was committed on Saturday, May 16, 2020 at around 02.30 WIB

- The intention was there to commit the crime.

Based on the facts, the statements of the witnesses and suspects and corroborated by the presence of evidence, the suspect Br. Suyatmin bin Tomo already intends to take 4 coconut seeds belonging to the Tusrin victim which is stored in a basket outside the house.

- People have started to commit these crimes.

Based on witness testimony and corroborated by the suspect's statement, Bro. Suyatmin bin Tomo has started to commit a crime by taking 4 coconut kernels outside the house using no means whatsoever.

- The action is finished only because of things that do not depend on the will of the maker himself.

Based on witness testimony and corroborated by the statement of the suspect, Suyatmin bin Tomo, the victim found out and shouted at the thief by the victim so that the perpetrator could be arrested by the residents.

Based on the testimony of the witnesses and the statement of the suspect and corroborated by the presence of evidence, Br. Suyatmin bin Tomo can be suspected or reasonably suspected of having committed a criminal act as referred to in Article 362 of the Criminal Code.

Based on the above discussion, the investigator is of the opinion:

That it was true that 4 coconut seeds were stolen on Saturday, May 16, 2020 in a basket outside your house. Tusrin, the address is Purwosari village RT 21 RW 04 Dist. Patebon Reg. Kendal. As referred to in article 362 of the Criminal Code.

So the cases described above can be seen in the investigation process of the criminal act of theft in the Kendal Police jurisdiction in carrying out law enforcement, namely conducting investigations, investigations and so on, having referred to the applicable rules, namely the Criminal Procedure Code and in the Criminal Application against theft with Article 362 of the Criminal Code.

As well as law enforcement against criminal acts of theft in the jurisdiction of the Kendal Police, it is carried out through investigations and investigations in accordance with the rules in Article 75 paragraph (1) of the Criminal Procedure Code, namely examination of suspects, arrest, detention, search, house entry, confiscation of objects, examination of letters, examination of witnesses, examination at the scene, implementation of court decisions and decisions and 
implementation of other actions in accordance with the provisions of this law. ${ }^{5}$

Law enforcement on cases of theft in the Kendal Police jurisdiction in accordance with Article 75 paragraph (1) of the Criminal Procedure Code, states that an official report is made for every action concerning the investigation of a suspect, arrest, detention, search, house entry, confiscation of objects, examination of letters, examination of witnesses. Examination at the scene, Implementation of court decisions and decisions and Implementation of other actions in accordance with the provisions of this law.

So that the implementation of the investigation process on criminal acts of theft in the Kendal Police jurisdiction in carrying out law enforcement is in accordance with law enforcement theory mentioned in on which the factors that influence law enforcement as stated by Suryono Soekanto consist of. ${ }^{6}$

- The legal factor itself, which is limited in it only by law

- Law enforcement factors, namely the parties who form or implement the law

- Infrastructure factors that support law enforcement

- Community factors, namely the environment in which the law applies and is applied.

- Cultural factors, namely as a result of work, creativity and taste based on human initiative in social interactions.

And according to the theory of investigation which is based on the provisions of Article 75 paragraph (1) of the Criminal Procedure Code, it is stated that an official report is made for each action concerning:

- Suspect examination

- Arrest

- Detention

- Search

- Home income

- Confiscation of objects

- Mail check

- Witness examination

- Examination at the scene

- Implementation of court decisions and decisions

- The implementation of other actions in accordance with the provisions of this law.

Related to the example of the case of theft of 4 coconut seeds, the implementation of the criminal law enforcement process for the theft of the Kendal Police was in accordance with Article 12 Perkap Polri No. 6 of 2019 with peaceful efforts, namely restorative justice even though the elements of this criminal act have been fulfilled and can be submitted to court.

\subsection{Factors that influence law enforcement against the perpetrators of}

\footnotetext{
${ }^{5}$ Interview with Brigadier Ahmad Widodo, Semarang Police Assistant Investigator

6 Satria Ardi Yana and Bambang Tri Bawono, "Effectiveness of Implementing ITE Laws and Investigations of Damnation through Social Media" Jurnal Daulat Hukum, Volume 2 Issue 3, September 2020, p. 435. http://jurnal.unissula.ac.id/index.php/ldj/article/view/11993
} 


\section{criminal acts of theft at the Kendal Police who are just}

The factors that influence law enforcement against perpetrators of criminal acts of theft encountered by the author in the field are as follows: ${ }^{7}$

- There is an unclear report from someone regarding a criminal act of theft Many whistleblowers have reported incidents of theft but were unable to provide detailed or complete information on the case to the officer regarding the chronology of the crime from beginning to end.

Because most reporters only glimpse or only hear about the incident after a criminal case has occurred, so the report is not clear, making the officer who receives the report experiencing difficulties in mapping the initial steps to deal with the reported theft crime.

- The unwise nature of the reporting party

Sometimes a reporter who is a victim of a criminal act of theft wants his report to be forwarded to the court process regardless of the situation and condition of the reported person or the perpetrator of the crime of theft in committing the theft. Even though the loss is not much, efforts should be made for peace.

- Difficulty finding information related to the crime of theft

Difficult to find information sometimes lack of support from the surrounding community in law enforcement against perpetrators of criminal acts such as blocking officers from arrest, confiscation of evidence, search and so on.

The role of the community is so influential in the occurrence of a crime because sometimes the community gets in the way because the perpetrator is still related to the family or the community who takes justice into their own hands when the perpetrator is caught by the masses. So that officers have difficulty finding materials for information about the case.

- Difficulty finding evidence, which can make light of the crime of theft.

Includes the lack of evidence as well as the lack of clues to the crime because the perpetrator of the theft manipulates or deceives the former crime by tricking the perpetrator who tends to be more planned, the damage to the crime scene/crime scene is caused by the large number of ordinary people who do not understand the importance of the crime scene/TKP.

So that in identifying the scene of the incident it is no longer pure because there have been many new traces of the community that will be seen because it is the thinking power of the community who thinks that someone dealing with the police is something against that person in society even though their capacity is only as a witness.

\subsection{Constraints that arise in the criminal law enforcement process theft at the Kendal Police which is just and the solution}

Efforts to overcome obstacles in overcoming a criminal act of theft include: 8

\subsubsection{Internal constraints:}

\footnotetext{
${ }^{7}$ Interview with Bripka Suwarto as Assistant Investigator of Kendal Police, in Kendal

${ }^{8}$ AKP Hartono, SH, Op. Cit
} 
- The lack of professional investigators with at least a bachelor's degree or law degree. Efforts to overcome:

Increase the human resources of the police in terms of investigations, in order to uncover a criminal case so that there is a need for continuous training and for the government if necessary to provide study time for investigators by providing opportunities with free tuition fees or scholarships to pursue undergraduate education or law degree.

- The lack of Budget support (DUKGAR) from the government for fingerprints and searches.

Efforts to overcome: So that the government provides an unlimited special budget so that in carrying out the duties of law enforcement officers it is easier to complete cases, especially the criminal act of theft, not to be burdened with operational costs.

- Lack of logistical support (DUKLOG) such as sophisticated facilities and infrastructure. Efforts to overcome: The government should provide the police with adequate facilities and infrastructure and keep up with the times or modern developments, both administrative and non-administrative. Providing sophisticated facilities and infrastructure, in order to make it easier to uncover a criminal act that has occurred. Thus the police will efficiently and effectively prevent criminal acts of theft.

\subsubsection{External constraints}

- The difficulties in disclosing theft cases include the minimum number of witnesses at the crime scene, the lack of evidence and the lack of evidence of the crime. Efforts to overcome: Providing understanding and counseling to the public about matters relating to criminal acts that occur in the vicinity and immediately reporting to the police quickly.

Provide/put up a police line at the crime scene, so that the scene is still mummified and there are no new traces from the community. Providing understanding to the public of the meaning and importance of witnesses in a case incident in order to reveal a criminal act that occurred.

- TKP locations or geographic locations that are difficult to reach, for example valleys, forests, mountains and so on. Efforts to overcome: It takes a sophisticated tactical and detection car fleet equipped with modern weaponry to capture the perpetrators.

- There was no wise attitude from the victim or the reporter to keep asking for the case to be forwarded to the trial even though the losses were insignificant; Efforts to overcome: Providing an understanding of the wise attitude towards victims so that they can take the path of peace because of the minimal material losses.

- There is no support from the surrounding community in enforcing the law against perpetrators of criminal acts such as preventing officers from arresting, confiscating evidence, searches and so on. Efforts to overcome: Conducting continuous and programmed legal counseling to the community, both in the city or village community, in the village, at school, in public places and so on so that it is hoped that the community will understand legal awareness, especially 
about criminal acts.

- The difficulty of the victim's role in the occurrence of a criminal act of theft also deserves attention and becomes an important factor in the occurrence of the crime of theft. Efforts to overcome: So that the victims here are more careful and alert to every suspicious person who is nearby, so that the crime of theft does not occur. Victims do not need to show their belongings and show them off on the streets.

\section{Closing}

From the description above, the authors conclude that the law enforcement process against criminal acts of theft in the jurisdiction of the Police has referred to the applicable rules, namely the Criminal Procedure Code (KUHAP) and the Criminal Procedure Code (KUHP) and Perkap Polri No. 6 years. 2019 concerning Criminal and Perma Investigation No. 2 of 2012 regarding the adjustment of the limits on minor crimes and the amount of fines in the Criminal Code and investigators are required to make an investigation plan that is submitted to the investigator's superior in stages and is related to theft below a nominal value of IDR. 2,500,000, preferably restorative. Many factors influence law enforcement against the perpetrators of the crime of theft at the Kendal Police along with the obstacles that arise. Various efforts are made to overcome them.

\section{References}

\section{Journals and Internet:}

[1] Muhammad Taufiq, "Penyelesaian Perkara Pidana Yang Berkeadilan Substansial" dalam Yustisia Vol2 No.1 January - April 2013, https://jurnaluns.ac.id/yustisia/article/viewFile/11058/9896

[2] https://sarjanahukumasli.blogspot.com/2018/05/makalah-tindak-pidanapencurian.html

[3] Satria Ardi Yana dan Bambang Tri Bawono, "Effectiveness of Implementing ITE Laws and Investigations of Damnation through Social Media" Jurnal Daulat Hukum, Volume 2 Issue 3, September 2020, p. 435. http://jurnalunissula.ac.id/index.php/ldj/article/view/11993

\section{Books:}

[1] Achmad Sulchan, Akhmad Khisni, and Aryani Witasari. (2020). Pola Pembinaan Narapidana Yang Berkeadilan. Semarang: Unissula Press.

[2] Moch Faisal Salam. Hukum Acara Pidana dalam Teori dan Praktek. Jakarta: Mandar Maju, 